\title{
ДОСЛІДЖЕННЯ ЗАСОБАМИ КОРЕЛЯЦІЙНОГО АНАЛІЗУ ДІЯЛЬНОСТІ УЛЬТРАСТРУКТУР ПРОФІЛЮ ТРАНСПОРТУВАЛЬНОЇ МОЖЛИВОСТІ ФОЛІКУЛЯРНИХ ТИРОЦИТІВ
}

\author{
O. I. Рябуха
}

\section{Львівський медичний інститут}

\begin{abstract}
Використання математичних методів для вивчення морфо-сункціональних особливостей сролікулярних тироцитів при коригуванні аліментарного дефіциту йоду $є$ актуальним завданням цитофрізіології. Метою роботи стало за умов дефріциту йоду в раціоні дослідити особливості взаємозв'язків між ультраструктурами фоолікулярних тироцитів транспортувального напряму їх діяльності (базальної цитоплазматичної мембрани, перикапілярного простору, мікрокапілярного русла, ендотеліоцитів) при прийманні органічного і неорганічного йоду. Об'єкт дослідження: електронограми щитоподібних залоз білих щурів-самців, яким десіцит йоду в раціоні коригували гістологічно встановленою мінімально діючою дозою органічного та неорганічного йоду. Встановлено, що лінгвістична (описова) характеристика стану ультраструктур тироцитів $€$ інорормативною, проте не дозволяє з'ясувати особливості їх взаємовпливів і взаємозалежностей. За допомогою аналізу кореляційних портретів установлено, що в умовах аліментарного десріциту йоду порушується стан мікрокапілярного русла, тоді як приймання органічного та неорганічного йоду покращує його морфофрункціональний стан. При аліментарному дефіциті йоду поліпшення гемоциркуляції у мікрокапілярному руслі щитоподібної залози йодом органічної і неорганічної хімічної природи забезпечується різними ультраструктурними складовими елементами профрілю транспортувальної можливості фолікулярних тироцитів: при прийманні органічного йоду воно проявляється через оптимізацію кореляційних зв'язків між фролікулярними тироцитами зі збільшеною складчастістю їхніх цитоплазматичних базальних мембран і незміненими ендотеліоцитами, при прийманні неорганічного йоду — кореляційних зв'язків між перикапілярним простором помірної ширини та гіпертросованими ендотеліоцитамиі.
\end{abstract}

Ключові слова: щитоподібна залоза, сролікулярний тироцит, органічний йод, неорганічний йод, кореляційний аналіз, кореляційний портрет.

\section{STUDY OF ULTRASTRUCTURE PROFILE OF FOLLICULAR THYROCYTES' TRANSPORT CAPABILITIES BY MEANS OF CORRELATION ANALYSIS}

\section{O. I. Ryabukha}

\section{Lviv Medical Institute}

Background. The use of mathematical methods to study the morpho-functional features of follicular thyrocytes in the correction of alimentary iodine deficiency is an urgent task of cytophysiology. The purpose of this work is to study the peculiarities of the relationship between the ultrastructures of follicular thyrocytes in the transport direction of their activity (basal cytoplasmic membrane, pericapillary space, microcapillary bed, endotheliocytes) when taking organic and inorganic iodine.

Material and methods. The object of the study were electronograms of the thyroid glands of white male rats, whose iodine deficiency in the diet was corrected histologically with the minimum effective dose of organic and inorganic iodine. The research methods were linguistic description of electronograms. Method of semi-quantitative analysis of electronograms, Method on specifying the profiles of special capabilities of hormone-poietic cells, correlation analysis with the construction of correlation portraits.

Results. It is established that the linguistic (descriptive) characteristic of the thyrocyte ultrastructures' state is informative, but does not allow to clarify the features of their mutual influence and interdependencies. Analysis of correlation portraits revealed that in the conditions of alimentary iodine deficiency the state of the microcapillary bed is disturbed, while the intake of organic and inorganic iodine improves its morpho-functional state.

Conclusions. With alimentary iodine deficiency, the improvement of hemocirculation in the microcapillary bed of the thyroid gland by iodine of organic and inorganic chemical nature is provided by various ultrastructural components of the transport capability profile of follicular thyrocytes: when taking organic iodine, it is manifested by optimization of correlations between follicular thyrocytes with significant folding of their cytoplasmic basal membranes and unchanged endotheliocytes, when taking inorganic iodine - by correlations between the pericapillary space of moderate width and hypertrophied endotheliocytes.

Key words: thyroid gland, follicular thyrocyte, organic iodine, inorganic iodine, correlation analysis, correlation portrait. 


\title{
ИССЛЕДОВАНИЕ СРЕДСТВАМИ КОРРЕЛЯЦИОННОГО АНАЛИЗА ДЕЯТЕЛЬНОСТИ УЛЬТРАСТРУКТУР ПРОФИЛЯ ТРАНСПОРТНОЙ ВОЗМОЖНОСТИ ФОЛЛИКУЛЯРНЫХ ТИРОЦИТОВ
}

\author{
О. И. Рябуха
}

\section{Львовский медицинский институт}

\begin{abstract}
Использование математических методов для изучения морфофрункциональных особенностей фролликулярных тироцитов при коррекции алиментарного десицита йода является актуальной задачей цитофризиологии. Целью работы стало в условиях десрицита йода в рационе исследовать особенности взаимосвязей между ультраструктурами фролликулярных тироцитов транспортного направления их деятельности (базальной цитоплазматической мембраны, перикапиллярного пространства, микрокапиллярного русла, эндотелиоцитов) при приёме органического и неорганического йода. Объект исследования: электронограммы щитовидной железы белых крыс-самцов, которым деорицит йода в рационе корректировали гистологически установленной минимально действующей дозой органического и неорганического йода. Методы исследования: лингвистическое описание электронограмм, полуколичественный анализ электронограмм, метод определения профилей специальных возможностей гормонпоэтических клеток, корреляционный анализ с построением корреляционных портретов. Установлено, что лингвистическая (описательная) характеристика состояния ультраструктур тироцитов является иноормативной, однако не позволяет определять особенности их взаимовлияния и взаимозависимости. При помощи анализа корреляционных портретов установлено, что в условиях алиментарного десицита йода нарушается состояние микрокапиллярного русла, тогда как приём органического и неорганического йода улучшает его морфофункциональное состояние. При алиментарном дефриците йода улучшение гемоциркуляции в микрокапиллярном русле щитовидной железы йодом органической и неорганической химической природы обеспечивается различными ультраструктурными составляющими элементами профиля транспортной возможности фолликулярных тироцитов: при приёме органического йода оно проявляется через оптимизацию корреляционных связей между фролликулярными тироцитами с увеличенной складчатостью их цитоплазматических базальных мембран и неизменёнными эндотелиоцитами, при приёме неорганического йода - корреляционных связей между перикапиллярным пространством умеренной ширины и гипертрофированными эндотелиоцитами.
\end{abstract}

Ключевые слова: щитовидная железа, сролликулярный тироцит, органический йод, неорганический йод, корреляционный анализ, корреляционный портрет.

Вступ. Нинішній структурі загальної ендокринної захворюваності притаманне зростання рівня тиреоїдної патології та прискорення його темпів [11]. Водночас тиреоїдні гормони (ТГ) як облігатні учасники всіх видів обміну необхідні для диференціювання та зростання тканин, калорігенезу, діяльності переважної більшості органів і систем [10]. У такому разі патологія щитоподібної залози (Щ3) не є локальним порушенням діяльності одного органу — у хворобливий процес залучається практично весь організм. Значну частку тиреоїдних розладів становлять стани, спричинені зменшенням надходження йоду та зниженням активності залози. Традиційно профілактику та коригування таких станів здійснюють неорганічними йодовмісними сполуками - йодатами та йодидами, проте $\epsilon$ дані, що неорганічний йод може порушувати діяльність Щ3 [4]. Як альтернатива пропонується використання сполук органичного йоду [2], серед яких особливо перспективними вважають йодовмісні сполуки морських водоростей [3]. Отже, попри потребу в додатковому введенні йоду в організм при його недостатності, питання про вибір хімічної природи спожитої йодовмісної сполуки потребує поглибленого дослідження, чого можна досягнути порівнянням особливостей гормонопоезу при прийманні в якості субстрату для синтезу ТГ йоду органічної та неорганічної хімічної природи. Зазначене актуалізує потребу в застосуванні сучасних доказових методів для поглибленого вивчення діяльності ЩЗ при вживанні йоду різної хімічної природи.

Будь-яка клітина гормонопоетичного ряду функціонує за наявності ультраструктур, що виробляють гормональний продукт, ультраструктур, що його виділяють, ультраструктур, що здійснюють енергетичне забезпечення цих процесів, та ультраструктур, які реалізують надходження гормону в загальне кров'яне русло через інтраорганну мікрокапілярну сітку [1]. Своєю чергою інтенсивність гормонопоезу може бути незначною, помірною або значною, а характерні ознаки 
зазначених станів можуть бути морфологічними або/і функціональними. Докладне вивчення ультрастуктури клітин в умовах норми та патології і динаміку їхньої перебудови під впливом різноманітних чинників дає змогу метод електронної мікроскопії. До недавнього часу вивчення ультратонкої структури клітин ЩЗ здійснювали переважно описовим способом (словами вживаної мови). Проте такий метод дослідження має низку суттєвих вад, основними з яких є суб'єктивність в оцінюванні змін ультраструктурної картини та неможливість подальших математичних перетворень отриманих даних.

Прикметною рисою сучасного етапу розвитку медичної науки стало використання математичних методів [7]. Такий підхід до дослідження дає змогу чітко формулювати гіпотези про залежність одних явищ від інших. У такому разі використання відповідних математичних методів для поглибленого вивчення діяльності ЩЗ при прийманні йодовмісних сполук різної хімічної природи стає обгрунтованим і доцільним. Водночас нами не знайдено відомостей про застосування математичних методів при дослідженні ультраструктур транспортувального напряму діяльності фолікулярних тироцитів і оцінювання їхнього стану, зокрема в умовах приймання органічного та неорганічного йоду на тлі аліментарного дефіциту йоду.

Мета дослідження: за умов дефіциту йоду в раціоні дослідити особливості взаємозв'язків між ультраструктурами фолікулярних тироцитів танспортувального напряму їх діяльності при прийманні органічного та неорганічного йоду.
Матеріал і методи дослідження. Дослідження проведено на 40 білих нелінійних щурах-самцях початкової маси тіла 140-160 г, що впродовж 30 днів перебували в стандартних умовах віварію. Щурі групи 1, що споживали загальновіварний корм, були універсальним контролем для щурів інших груп. Щурі груп 2, 3, 4 споживали крохмально-казеїновий раціон, в який водо- та жиророзчинні вітаміни надходили в кількостях, рекомендованих для тварин даного виду та маси тіла. Джерелом макро- і мікроелементів була сольова суміш, з якої для створення моделі аліментарного дефіциту йоду було еліміновано йодовмісні сполуки. Харчову суміш, що щурам кожної групи готували в окремому посуді, закладали в годівниці один раз на добу зранку після прибирання кліток, зважування залишків їжі та перерахунку вмісту йоду. Доступ щурів усіх груп до напувалок із дистильованою водою був вільним. Коригування стану йодного голодування щурам груп 3 і 4 здійснювали органічним і неорганічним йодом, що вони споживали в гістологічно визначеній мінімально діючій дозі 21 мкг/кг ваги тіла. Щурі 3 групи споживали органічний йод, джерелом якого був йодобілковий препарат із чорноморської червоної водорості філофори ребристої (Phyllophora nervosa) [5], неорганічний йод надходив у раціон щурів 4 групи 3 калієм йодидом. У раціон щурів групи 2, що були додатковим контролем для тварин груп 3 і 4, сполуки йоду не додавали (табл. 1).

Умови дослідження по вивченню впливу мінімально діючої дози органічного та неорганічного йоду в умовах дефіциту йоду в раціоні $(\mathrm{n}=40)$

\begin{tabular}{|c|c|c|c|}
\hline $\begin{array}{c}\text { Група } \\
\text { тварин }\end{array}$ & Умови досліду & $\begin{array}{c}\text { Хімічна природа } \\
\text { йоду, що додавали } \\
\text { до раціону }\end{array}$ & $\begin{array}{c}\text { Кількість йоду, що } \\
\text { додавали до раціону, } \\
\text { (мкг/кг маси тіла) }\end{array}$ \\
\hline $\begin{array}{c}1 \\
(\mathrm{n}=10)\end{array}$ & Повноцінний загальновіварний корм & - & - \\
\hline $\begin{array}{c}2 \\
(\mathrm{n}=10)\end{array}$ & $\begin{array}{c}\text { Дефіцит йоду в раціоні (фоновий вміст } \\
\text { йоду 13-15 мкг/кг маси тіла) }\end{array}$ & - & 21 \\
\hline $\begin{array}{c}3 \\
(\mathrm{n}=10)\end{array}$ & $\begin{array}{c}\text { Дефіцит йоду в раціоні (фоновий вміст } \\
\text { йоду 13-15 мкг/ кг маси тіла) }\end{array}$ & органічна & 21 \\
\hline $\begin{array}{c}4 \\
(\mathrm{n}=10)\end{array}$ & $\begin{array}{c}\text { Дефіцит йоду в раціоні (фоновий вміст } \\
\text { йоду 13-15 мкг/ кг маси тіла) }\end{array}$ & неорганічна & 21 \\
\hline
\end{tabular}


Після закінчення строку спостереження щурі були декапітовані під ефірним наркозом, їхні ЩЗ - ретельно відсепаровані від сполучної тканини та підготовлені до електронномікроскопічного дослідження за стандартними методиками. Кількісні параметри, отримані при вивчені на електронограмах ЩЗ щурів кожної групи стану складових елементів транспортувального напряму діяльності фолікулярних тироцитів, оброблено методами математичної статистики з використанням програми StatSoft Statistica v6.0; усереднені показники кожного складового елементу слугували для побудови кореляційних портретів. Для кореляційних таблиць і портретів використано пакет Microsoft Office 2010 - електронні таблиці MS Excel i графічний редактор MS Word (Microsoft Graph), відповідно. На всіх етапах дослідження було дотримано принципи біоетики відповідно до Європейської конвенції про захист хребетних тварин, яких використовують в експерименті (Страсбург, 1986) та Директиви Ради Європи 2018/63/CV, статті 26 Закону України від 21.02.2006 № 3447-IV «Про захист тварин від жорстокого поводження».

Електронномікроскопічний метод дослідження. Щитоподібні залози щурів фіксувалися у чотириокису осмію та зневоднювалися в спиртах висхідної концентрації і ацетоні з подальшою полімеризацією в епоксидних смолах. Виготовлені на ультрамікротомі LKB 8800 (Швеція) ультратонкі зрізи залоз товщиною 4-6 мкм додатково контрастували солями ураніл-ацетата та цитрата свинцю і вивчали під електронним мікроскопом Selmi ТЕМ-100-01 (Україна).

Лінгвістичний опис. Лінгвістичний опис полягав у використанні слів уживаної мови для характеристики досліджуваних явищ.

Напівкількісний аналіз електронограм [6]. Метод дозволив трансформувати якісні дані про клітину в кількісні. Отримані цифрові параметри усереднювали та використовували для подальших математичних перетворень, зокрема при проведенні кореляційного аналізу для визначення взаємозв'язків і взаємозалежностей між ультраструктурними компонентами досліджуваних напрямів діяльності фолікулярних тироцитів.

Метод визначення профілів спеціальних можливостей гормонопоетичних клітин [6]. Ультраструктурними складовими елементами профілю транспортувальної можливості фолікулярних тироцитів є базальна цитоплазматична мембрана фолікулярного тироцита, перикапілярний простір, ендотеліоцити мікрокапілярів, стан інтраорганного мікрокапілярного русла. Ранжовані складові елементи профілю представлено в табл. 2.

\section{Профіль транспортувальних можливостей фолікулярних тироцитів}

\begin{tabular}{|c|c|c|c|}
\hline $\begin{array}{c}\text { Ультраструктурний } \\
\text { елемент }\end{array}$ & $\begin{array}{c}\text { Досліджувана ознака } \\
\text { ультраструктурного } \\
\text { елемента }\end{array}$ & $\begin{array}{c}\text { Якість ознаки } \\
\text { досліджуваного } \\
\text { ультраструктурного } \\
\text { елемента }\end{array}$ & $\begin{array}{c}\text { Умовна позначка якості } \\
\text { ознаки досліджуваного } \\
\text { ультраструктурного } \\
\text { елемента }\end{array}$ \\
\hline \multirow{3}{*}{$\begin{array}{c}\text { Базальна } \\
\text { цитоплазматична } \\
\text { мембрана }\end{array}$} & \multirow{3}{*}{ складчастість } & незначна & $\mathrm{P} 1$ \\
\hline & & помірна & $\mathrm{P} 2$ \\
\hline & & значна & P3 \\
\hline \multirow{5}{*}{$\begin{array}{c}\text { Перикапілярний } \\
\text { простір }\end{array}$} & \multirow{3}{*}{ ширина } & незначна & Q1 \\
\hline & & помірна & Q2 \\
\hline & & значна & Q3 \\
\hline & \multirow{2}{*}{ включення } & наявні & Q4 \\
\hline & & відсутні & Q5 \\
\hline \multirow{3}{*}{ Ендотеліоцити } & \multirow{3}{*}{ стан } & гіпотрофовані & $\mathrm{R} 1$ \\
\hline & & нормальні & $\mathrm{R} 2$ \\
\hline & & гіпертрофовані & R3 \\
\hline
\end{tabular}




\begin{tabular}{|c|c|c|c|}
\hline \multirow{3}{*}{ Ендотеліоцити } & \multirow{3}{*}{ псевдоподії } & незначні & $\mathrm{R} 4$ \\
\hline & & помірні & R5 \\
\hline & & значні & R6 \\
\hline \multirow{6}{*}{ Мікрокапілярне русло } & \multirow{6}{*}{ стан } & без особливостей & $\mathrm{S} 1$ \\
\hline & & явища стазу & $\mathrm{S} 2$ \\
\hline & & наявність еритроцитів & S3 \\
\hline & & явища тромбозу & $\mathrm{S} 4$ \\
\hline & & $\begin{array}{c}\text { наявність опасистих } \\
\text { клітин }\end{array}$ & S5 \\
\hline & & $\begin{array}{c}\text { наявність ниток } \\
\text { фібрину }\end{array}$ & S6 \\
\hline
\end{tabular}

Кореляційний аналіз. Метод кореляційного аналізу [13] застосовували для встановлення взаємозв'язків між досліджуваними складовими елементами профілю транспортувальної можливості фолікулярних тироцитів. Визначався лінійний коефіцієнт кореляції Пірсона (r). Силу кореляційних зв'язків визначали за шкалою Чеддока, також ураховували напрям зв'язків та їхню кількість. Найбільш значущими вважали дуже високі та високі зв'язки, що за шкалою кореляції Чеддока перебувають відповідно в межах 1,00 $\geq|\mathrm{r}| \geq 0,91$ та $0,90 \geq|r| \geq 0,71$; у разі відсутності таких зв'язків враховували помітні зв'язки $(0,70 \geq|r| \geq 0,51)$ та помірні зв'язки $(0,50 \geq|r| \geq 0,31)$. Простежені кореляційні зв'язки між структурними складовими досліджуваного транспортувального напряму діяльності фолікулярних тироцитів графічно унаочнювалися створенням кореляційних портретів [12].

Цитофізіологічне дослідження. Основою для інтерпретації кореляційних портретів профілю транспортувальної можливості фолікулярних тироцитів щурів досліджуваних груп були дані цитофізіології про функціональне значення клітинних ультраструктур та їхні електронномікроскопічні характеристики [8, 9].

Результати та їх обговорення. Для дослідження особливостей впливу йоду різної хімічної природи на транспортування гормонального продукту, виробленого фолікулярними тироцитами, при побудові кореляційних портретів їх функціонально важливими складовими (опорними точками) було визначено помірну складчастість цитоплазматичної мембрани (Р2), помірну ширину перикапілярного простору (Q2), нормальний стан ендотеліоцитів (R2), мікрокапілярне русло без особливостей (S2). Побудова кореляційних портретів проводилася на основі визначених у кожній групі їхніх індивідуальних складових елементів (фактичних ознак).

1. Лінгвістична характеристика профілю транспортувальної можливості фолікулярних тироцитів інтактних щурів (група 1).

Базальний прекапілярний полюс фолікулярних тироцитів інтактних щурів помірно складчастий, перикапілярний простір — щілиноподібний, ендотелій інтратиреоїдних мікрокапілярів - помірно розширений, псевдоподії ендотеліоцитів - поодинокі. В мікросудинному інтратиреоїдному руслі включень і формених елементів не спостерігається.

1.1. Кореляційний портрет профілю транспортувальної можливості фолікулярних тироцитів інтактних щурів (група 1) із інтерпретацією результатів кореляційного аналізу. Фактичними ознаками кореляційного портрету (рис. 1) були Р2, Q1, Q5, R2, R4, S1, між якими простежено такі зв'язки: дуже високі $(1,00 \geq|\mathrm{r}| \geq 0,91)-2$; міцні $(0,90 \geq|r| \geq 0,71)-0$; помітні $(0,70 \geq|r| \geq 0,51)-2$; помірні $(0,50 \geq|r| \geq 0,31)-6$ (усі непрямі).

Дуже високий зв'язок $(\mathrm{r}=1,0)$ перикапілярного простору незначної ширини (Q1) із нормальним станом ендотеліоцитів (R2) свідчить про наявність умов, сприятливих для транспортування випродукуваного гормонального продукту мікрокапілярним руслом. Зв' язок такої ж сили та напряму $(\mathrm{r}=1,0)$ між відсутністю включень у перикапілярному просторі (Q5) та незначними розмірами ендотеліоцитарних псевдоподій (R4) підтверджує попередній 
висновок про наявність умов для оптимального інтраорганного транспортування тиреоїдних гормонів кров’яним руслом. Помітні зв'язки $(\mathrm{r}=0,61)$ простежено між фолікулярними тироцитами з помірною складчастістю базальних мембран (Р2), ендотеліоцитами 3 незначними псевдоподіями (R4) та перикапілярним простором із відсутністю включень (Q5), також вказують на умови, сприятливі для плину крові.

Непрямі зв’язки помірної сили $(\mathrm{r}=-0,41)$ встановлені між Р2, перикапілярним простором незначної ширини (Q1) та незміненими (нормальними) ендотеліоцитами (R2), дозволяють нам припустити, що в умовах еутиреозу транспортування тиреоїдних гормонів може відбуватися за умов розширення перикапілярного простору та зміни морфологічного стану ендотеоліцитів. На нашу думку, зазначене є ознакою значного пристосувального потенціалу тироциту. Висловлене припущення може бути підтверджене зв’язками такої ж сили та напряму ( $\mathrm{r}=-0,41)$, простеженими між (стан мікрокапілярного русла без особливостей) та Q1, Q5, R2, R4 (незначні розміри псевдоподій ендотеліоцитів).
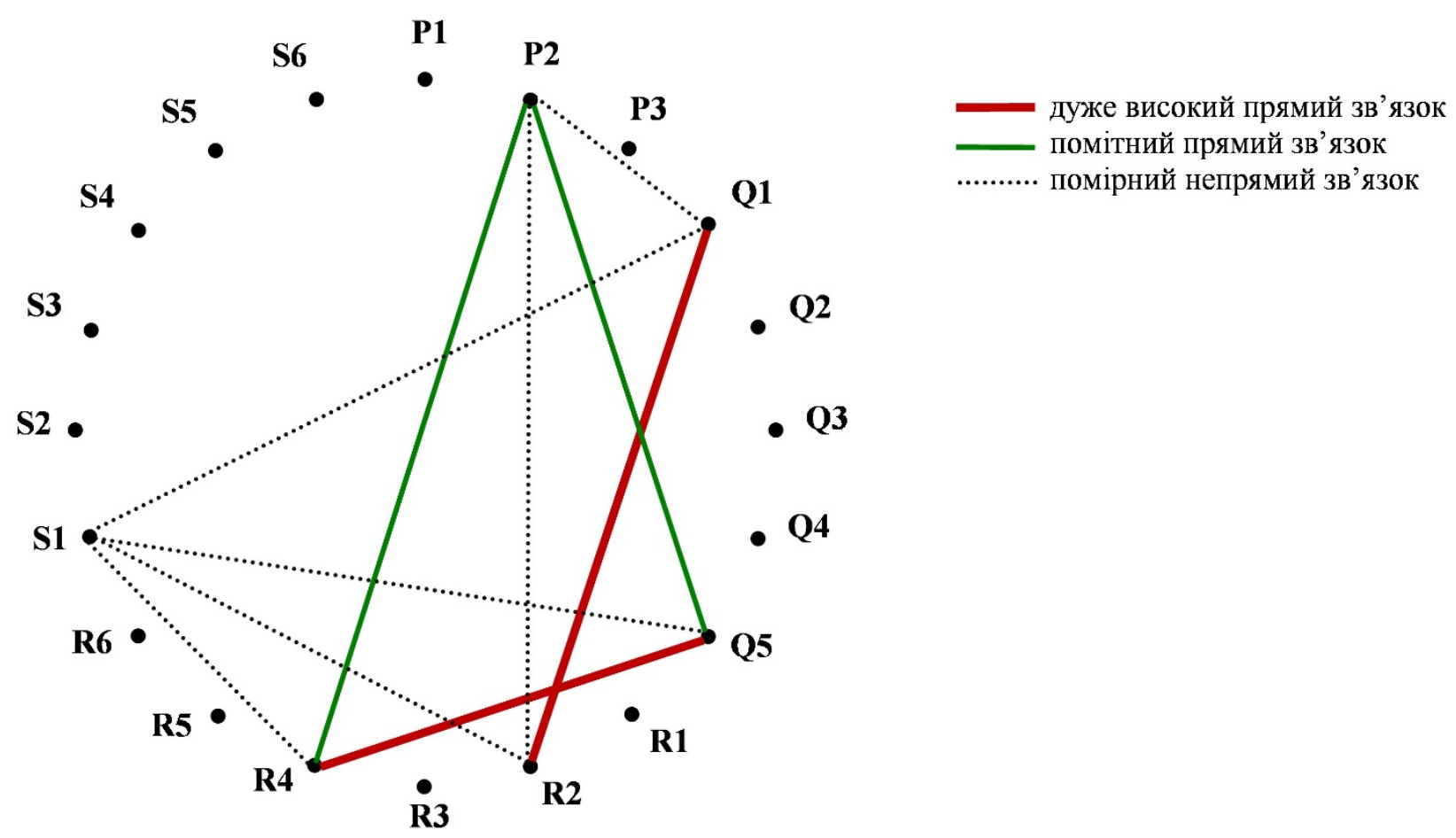

Рис. 1. Графічне зображення структури кореляційного портрету профілю транспортувальної можливості фолікулярних тироцитів інтактних щурів (група 1)

\section{2. Лінгвістична характеристика профілю} транспортувальної можливості фолікулярних тироцитів в умовах аліментарного дефіциту йоду (група 2)

В умовах аліментарного дефіцитну йоду базальний полюс фолікулярних тироцитів характеризується помірною складчастістю цитоплазматичної мембрани, перикапілярний простір залишається щілиноподібним, ендотелій мікрокапілярів має вигляд вузького обідка, ендотеліоцитарні псевдоподії не виражені, стан мікросудинного русла — без особливостей.

2.1. Кореляційний портрет профілю транспортувальної можливості фолікулярних тироцитів в умовах аліментарного дефіциту йоду (група 2) 3 інтерпретацією результатів кореляційного аналізу. Фактичними ознаками досліджуваного портрету (рис. 2) були P3, Q1, Q2, Q5, R2, R3, R5, $\mathrm{S} 1$, між якими простежено дуже високі зв'язки $(1,00 \geq|r| \geq 0,91)-1$ (непрямі), високі зв'язки 
$(0,90 \geq|\mathrm{r}| \geq 0,71)-1$, помітні зв'язки $(0,70 \geq|\mathrm{r}|$ $\geq 0,51)-5$ (4 непрямих), помірних зв'язків $(0,50 \geq|r| \geq 0,31)-7$, із них непрямих 4 .

Дуже високий непрямий зв'язок $(\mathrm{r}=-1,0)$ фолікулярних тироцитів зі значною складчастістю базальної цитоплазматичної мембрани (Р3), та перикапілярного простору незначної ширини (Q1) указує на наявність розладів внутрішньотиреоїдного плину крові. На певні утруднення в мікроциркуляції вказують такі зв' язки: помірної сили $(\mathrm{r}=0,41)$ між Р3 (значна складчастість базальної мембрани) та гіпертрофованими ендотеліоцитами (R3), помітний зв'язок (r=0,61) між R3 і відсутністю змін у мікрокапілярному руслі (S1), непрямий помітний зв'язок $(\mathrm{r}=-0,535)$ перикапілярного простору помірної ширини (Q2) i R3. Водночас зв'язок S1 помірної сили $(\mathrm{r}=0,41)$ з незміненими (нормальними) ендотеліоцитами (R2) та зв'язки S1 помітної сили $(\mathrm{r}=0,61)$ із гіпертрофованими (R3) ендотеліоцитами і тироцитами зі значною складчастістю базальних цитоплазматичних мембран (Р3) є ознакою того, що в досліджуваних умовах аліментарного гіпотиреозу можна реалізувати транспортувальний напрям діяльності фолікулярних тироцитів.

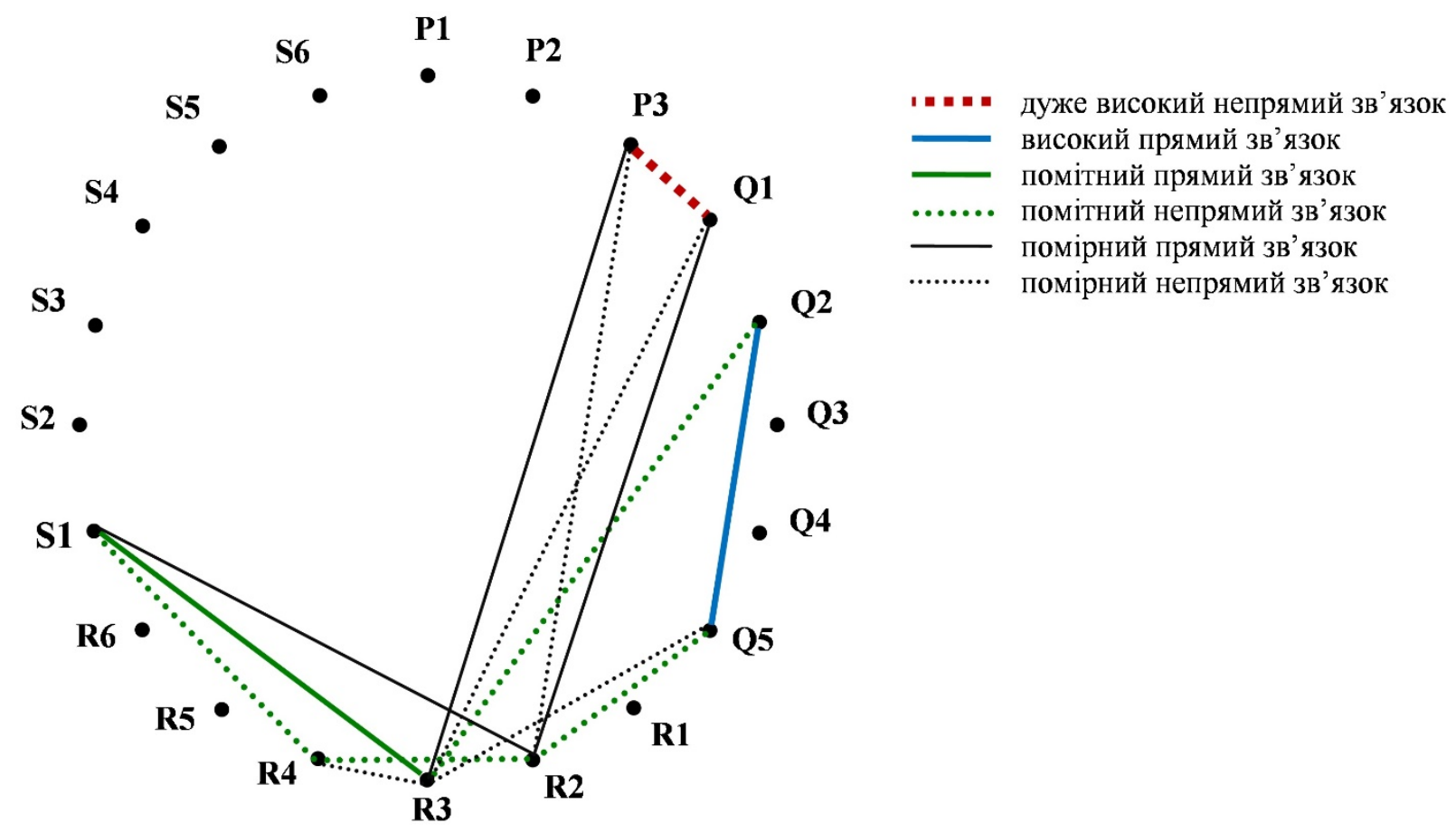

Рис. 2. Графічне зображення структури кореляційного портрету профілю транспортувальної можливості фолікулярних тироцитів в умовах аліментарного дефіциту йоду (група 2)

3. Лінгвістична характеристика профілю транспортувальної можливості фолікулярних тироцитів при прийманні 21 мкг органічного йоду в умовах аліментарного дефіциту йоду (група 3)

При споживанні щурами 21 мкг йоду органічної хімічної природи складчастість базальних цитоплазматичних мембран фолікулярних тироцитів добре виражена, перикапілярний простір - дещо розширений, кількість псевдоподій ендотелію мікрокапілярів — помірна. Установлені особливості профілю можуть бути ознакою певного посилення мікроциркуляції в судинному руслі, ймовірно зумовленого активізуванням анаболічних процесів обговорюваною дозою органічного йоду.

3.1. Кореляційний портрет профілю транспортувальної можливості фолікулярних тироцитів при прийманні 21 мкг органічного йоду в умовах аліментарного дефіциту йоду (група 3) з інтерпретацією результатів кореляційного аналізу. Фактичними ознаками при побудові портрету (рис. 3) були P3, Q2, Q3, Q5, R2, R3, R5, S1, між якими встановлено такі кореляційні зв'язки: дуже високі $(1,00 \geq|r| \geq 0,91)-3$ (із них непрямі - 2), помітні зв'язки $(0,70 \geq|r| \geq 0,51)-11$ (6 непрямих), помірних зв'язків $(0,50 \geq|r| \geq 0,31)-7$, із них непрямих 5. 
Основними вузловими точками портрету були R2 та R3 (незмінені та гіпертрофовані ендотеліоцити), що мали по 5 зв’язків. Дуже високий прямий зв’язок $(\mathrm{r}=1,0)$ фолікулярних тироцитів із значною складчастістю базальних цитоплазматичних мембран (P3) із незміненими (нормальними) ендотеліоцитами (R2) свідчить про поліпшення стану інтраорганного мікрокапілярного русла, що сприятиме оптимізуванню транспортування гормонального продукту. Про позитивний вплив 21 мкг органічного йоду на складові елементи профілю транспортувальних можливостей фолікулярних тироцитів також свідчать дуже високі непрямі 3в’язки між R3 (гіпертрофовані ендотеоліцити) та R2 i P3 (r=-1,0). На подібний напрям функціонування вказують зв’язки помітної сили $(\mathrm{r}=0,61)$ між Р3 і помірною шириною перикапілярного простору (Q2) та між ендотеліоцитами з псевдоподіями помірних розмірів (R5) і нормальним станом мікрокапілярного русла (Q1), а також дуже міцний непрямий зв’язок (r=-1,0) фолікулярних тироцитів із значною складчастістю базальних мембран (P3) із гіпертрофованими ендотеоліцитами (R3). Отже, приймання малої дози органічного йоду супроводжується формуванням великої кількості (13) непрямих зв’язків, що можна розглядати або як прояв здатності фолікулярних тироцитів до пристосування при функціонуванні в несприятливих умовах, або як ознаку нестабільності системи, що може проявлятися порушенням плину крові мікрокапілярним руслом при підвищенні вимог до кровопостачання.

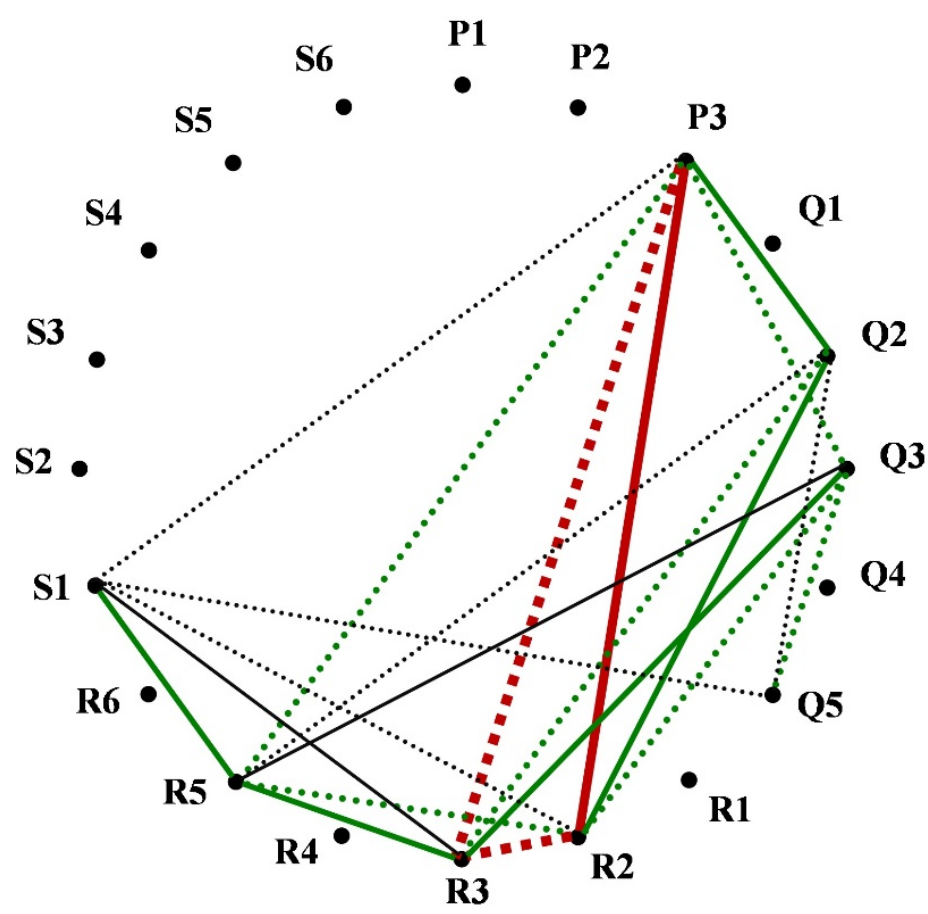

Рис. 3. Графічне зображення структури кореляційного портрету профілю транспортувальної можливості фолікулярних тироцитів при прийманні 21 мкг органічного йоду в умовах аліментарного дефіциту йоду (група 3)

\section{4. Лінгвістична характеристика профілю} транспортувальної можливості фолікулярних тироцитів при прийманні 21 мкг неорганічного йоду в умовах аліментарного дефіциту йоду (група 4)

Базальні мембрани фолікулярних тироцитів щурів, що споживали 21 мкг неорганічного йоду, характеризуються помірною складчастістю, перикапілярний простір - розширений, вирости капілярного ендотелію (ендотеліальні псевдоподії) — поодинокі; в мікросудинному руслі виявлено поодинокі тромбоцити, нитки фібрину, опасисті клітини. Установлені особливості електронномікроскопічної картини потребують подальшого дослідження оскільки можуть вказувати як на певні порушення інтратиреоїдної мікроциркуляції, так і на активізування механізмів пристосування до умов йодного голодування. 
4.1. Кореляційний портрет профілю транспортувальної можливості фолікулярних тироцитів при прийманні 21 мкг неорганічного йоду в умовах аліментарного дефіциту йоду (група 4) sз інтерпретацією результатів кореляційного аналізу. На основі побудованого кореляційного портрету (рис. 4) з'ясовано, що його фактичними характеристиками були P1, P2, Q2, Q3, Q5, R2, R3, R4, R5, S3, S5, S6, між якими встановлено такі кореляційні зв'язки: дуже високі $(1,00 \geq|r| \geq 0,91)-8$ ( помітні $0,70 \geq|r| \geq 0,51$ ) - 25 (з них непрямі - 17), помірні $(0,50 \geq|r| \geq 0,31)-6$ (з них непрямі -1$)$.

Дуже високий прямий зв'язок $(\mathrm{r}=1,0)$ перикапілярного простору помірної ширини (Q2) із гіпертрофованими ендотеліоцитами (R3) вказує на поліпшення мікроциркуляції, порушеної перебуванням на йододефіцитному раціоні. На це ж вказують дуже високі непрямі зв'язки $(\mathrm{r}=-1,0)$ перикапілярного простору значної ширини (Q3) із наявністю тромбоцитів, опасистих клітин і ниток фібрину в мікрокапілярному руслі (відповідно S3, $\mathrm{S} 5, \mathrm{S6})$, високий зв'язок $(\mathrm{r}=0,79)$ між ендотеліоцитами з псевдоподіями помірних розмірів (R5) i перикапілярним простором помірної ширини (Q2), а також помітний зв'язок ( $\mathrm{r}=0,65)$, простежений між R5 і незміненим станом ендотеліоцитів
(R2). При інтерпретації помітного зв'язку ( $\mathrm{r}=0,65)$, простеженого між перикапілярним простором значної ширини (Q3) й ендотелієм із псевдоподіями помірних розмірів (R5), схиляємося до тієї думки, що він може вказувати на умови, сприятливі для мікрокапілярного плину крові.

Водночас дуже високі зв'язки $(\mathrm{r}=1,0)$ між наявністю тромбоцитів і опасистих клітин у мікрокапілярному руслі (відповідно S3 і S5) та наявністю ниток фібрину (S6) вказують на певні перешкоди плину крові в мікрокапілярному руслі. На наявність таких перешкод можуть вказувати помітні $(\mathrm{r}=0,61)$ зв'язки, що простежено між фолікулярними тироцитами $з$ незначною складчастістю базальних мембран (P1) та значною шириною перикапілярного простору (Q3), між помірною шириною перикапілярного простору (Q2), та відсутністю включень у ньому (Q5), між Q3 та гіпертрофованим станом ендотеліоцитів (R3). Інтерпретація помітних (відповідно r=0,61 та r=0,65) зв'язків, простежених між відсутністю включень у перикапілярному просторі (Q5) і гіпертрофією ендотеліоцитів (R3) та між Q5 i ендотеліоцитами 3 незначними псевдоподіями (R4) потребує поглибленого вивчення. На нашу думку, така конфігурація може бути ознакою певних утруднень у реалізації транспортувального напряму діяльності тироциту.
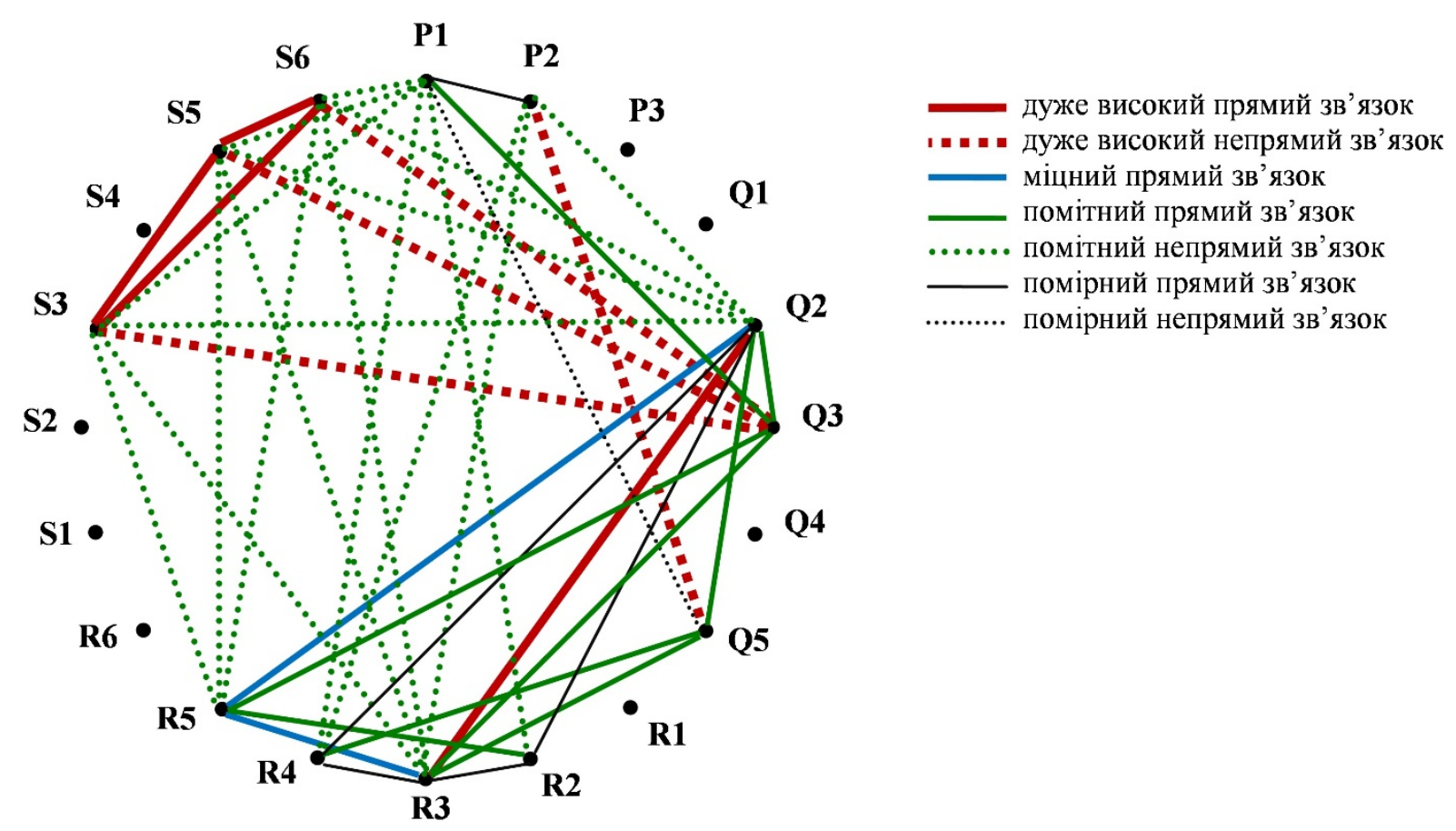

Рис. 4. Графічне зображення структури кореляційного портрету профілю транспортувальної можливості фолікулярних тироцитів при прийманні 21 мкг неорганічного йоду в умовах аліментарного дефіциту йоду (група 4) 
Отже, при прийманні органічного йоду поліпшення гемоциркуляції у мікросудинному руслі полягає в оптимізації кореляційних зв’язків між такими функціонально важливими складовими елементами профілю транспортувальної можливості фолікулярних тироцитів як збільшена складчастість базальних мембран фолікулярних тироцитів (P3) і незмінені ендотеліоцити (R2). При прийманні неорганічного йоду такими оптимізувальними елементами кореляційного портрету $є$ перикапілярний простір помірної ширини (Q2) і гіпертрофовані ендотеліоцити (R3).

Висновки. 1. Дослідження кореляційних портретів транспортувального напряму діяльності фолікулярних тироцитів дає змогу поглиблено дослідити механізми функціонування щитоподібної залози.

2. Лінгвістична (описова) характеристика стану ультраструктур транспортувального напряму діяльності фолікулярних тироцитів $є$ достатньо інформативною, проте не дає змоги вивчити особливості їх взаємовпливів і взаємозалежностей, що суттєво обмежує пізнавальний арсенал дослідника.

3. За умов аліментарного дефіциту йоду існує певний потенціал щодо транспортування виробленого гормонального продукту мікрокапілярним руслом щитоподібної залози.

4. Приймання малої дози (21 мкг/кг маси тіла) як органічного, так і неорганічного йоду на тлі аліментарного дефіциту йоду сприяє поліпшенню стану мікрокапілярного русла щитоподібної залози.

5. Поліпшення гемоциркуляції мікрокапілярним руслом щитоподібної залози при прийманні йоду різної хімічної природи за умов аліментарного дефіциту йоду забезпечується різними ультраструктурними складовими елементами профілю транспортувальної можливості фолікулярних тироцитів.

Перспективи подальших досліджень полягають у вивченні кореляційних портретів енергетичного напрямку діяльності фолікулярних тироцитів.

\section{Література.}

1. Автандилов Г. Г. Медицинская морфометрия: Руководство. Москва: Медицина, 1990. - 384 с.

2. Исследование профилактической эффективности биологически активной добавки биойод / Л. С. Большакова, Е. В. Литвинова, А. В. Кузина [и др.] // Фундаментальные исследования. 2013. - № 10, Ч. 11. - С. 2401-2404.

3. Вивчення впливу чорноморських водоростей на функцію щитоподібної залози та профілактику йододефіцитних станів. Екологія і захворювання щитоподібної залози / Корзун В. Н., Воронцова Т. О., Антонюк І. Ю. - К.: Медінформ, 2018. Гл. 10. - С. 607-622.

4. Нутриціологічна профілактика йодної недостатності / Лотоцька У. Б., Крупка Н. О. // Львівський медичний часопис. - 2011. - Т. 17, № 1. - С. 100-105.

5. Рябуха О. І. До питання застосування при гіпотиреозі неорганічного та органічного йоду (огляд) / Рябуха О. I. // Актуальні проблеми транспортної медицини. - 2018. - № 2. - С. 7-21.

6. Рябуха О. I. Перспективи застосування нових підходів до впровадження математичних технологій для вивчення діяльності клітини / Рябуха О. I. // Медична інформатика та інженерія. - 2018. № 1. - C. 67-75.

7. Теоретичні підходи до створення системної біомедицини (за матеріалами звіту НДР «Системно-

біологічні та системно-медичні закономірності розвитку і перебігу ішемічної хвороби серця) / О. П. Мінцер, Л. Ю. Бабінцева, В. М. Заліський [та ін.] // Медична інформатика та інженерія. 2020. - № 4. - C. 16-72.

8. Barrett E. J. The Thyroid Gland. Medical Physiology / Eds. W. F. Boron, E. L. Boulpaep. 3-rd ed. Philadelphia: Elsevier, 2016. - P. 1006-1017.

9. Caplan M. J. Functional Organization of the Cell. Medical Physiology / Eds. W. F. Boron, E. L. Boulpaep. 3-rd ed. Philadelphia: Elsevier, 2016. - P. 8-46.

10. Dietrich J. W., Landgrafe G., Fotiadou1 E. H. TSH and thyrotropic agonists: Key actors in thyroid homeostasis // Journal of Thyroid Research. - 2012. Vol. 2012, Article ID 351864. - P. 29.

11. Global epidemiology of hyperthyroidism and hypothyroidism / P. N. Taylor, D. Albrecht, A. Scholz G. [et al.] // Nat. Rev. Endocrinol. - 2018. - Vol. 15, No 5. - P. 301-316.

12. Ryabukha O., Dronyuk I. The portraits creating method by correlation analysis of hormone-producing cells data // CEUR Workshop Proc. - 2018. Vol. 2255. - P. 135-145.

13. Uurtio V. A tutorial on canonical correlation methods / V. Uurtio, J. M. Monteiro, J. Kandola [et al.] // ACM Computing Surveys. - 2018. - Vol. 50, No 6. - P. 1-33. 


\section{References.}

1. Avtandilov, G. G. (1990). Medical morphometry: A guide. Moscow: Meditsina. [in Russian].

2. Bolshakova, L.S., Litvinova, E.V., Kuzina, A.V., Lisicyn, A.B. \& Chernuha, I.M. (2013). Study of prophylactic effectiveness of the biologicalski active additives Bioiod. Fundamentalnyie issledovaniya - The fundamental researches, 10, 11, 2401-2404 [in Russian].

3. Korzun, V. N., Vorontsova, T.O. \& Antoniuk, I. Yu. (2018). Study of the Black Sea algae influence on thyroid function and prevention of iodine deficiency. In Ecology and diseases of thyroid gland. (p.p. 607622). Kyiv: Medinform. [in Ukrainian].

4. Lototska-Dudyk U. B., Krupka N. O. (2011). Nutritional prophilaxis of iodine deficiency. Acta Medica Leopoliensia, 17(1), 100-105. [in Ukrainian].

5. Ryabukha, O. I. (2018). To the problem of application in hypothyrosis inorganic and organic iodine (review). Actual problems of transport medicine, 2, 7-21. doi: 10.5281/zenodo.1319531 [in Ukrainian].

6. Ryabukha, O. I. (2018). Perspectives of applying new approaches to the implementation of mathematical technologies in the study of cell activity. Medical Informatics and Engineering, 1, 67-75. doi: 10.11603/ mie.1996-1960.2018.1.8894 [in Ukrainian].

7. Mintser, O. P., Babintseva, L. Yu., Zaliskyi, V. M., Popova, M. A., Nadutenko, M. V., Kharchenko, N. V. \& Ladychuk, O. K. (2020). Theoretical approaches to the creation of systemic biomedicine (Based on the materials of the report on SRW 'System-biological and system-medical regularities of development and course of ischemic heart disease'). Medical Informatics and Engineering, 4, 16-72. doi: 10.11603/ mie.1996-1960.2020.4.11889 [in Ukrainian].

8. Barrett, E. J. (2016). The thyroid gland, In W. F. Boron \& E. L. Boulpaep (Eds.), Medical Physiology, 3rd ed. (pp. 1006-1017). Philadelphia: Elsevier.

9. Caplan, M. J. (2016). Functional Organization of the Cell. In W. F. Boron \& E. L. Boulpaep (Eds.), Medical Physiology, 3rd ed. (pp. 8-46). Philadelphia: Elsevier.

10. Dietrich, J. W., Landgrafe, G., Fotiadou1, E. H. (2012). TSH and thyrotropic agonists: Key actors in thyroid homeostasis. Journal of Thyroid Research, 2012, ID 351864, 29. doi: 10.1155/2012/351864.

11. Taylor, P. N., Albrecht, D., Scholz, A., Gutierrez-Buey, G., Lazarus, J. H., Dayan, C. M. \& Okosieme, O. E. (2018). Global epidemiology of hyperthyroidism and hypothyroidism. Nat Rev Endocrinol, 15(5), 301-316. doi: 10.1038/nrendo.2018.18.

12. Ryabukha, O., Dronyuk, I. (2018). The portraits creating method by correlation analysis of hormoneproducing cells data. CEUR Workshop Proc, 2255, 135-145. URL: http://ceur-ws.org/Vol-2255/paper13. pdf.

13. Uurtio, V., Monteiro, J. M., Kandola, J., Shawe-Taylor, J., Fernandez-Reyes, D. \& Rousu, J. (2018). A tutorial on canonical correlation methods. ACM Computing Surveys, 50, 6 (95), 1-33. doi: 10.1145/3136624. 